Published in final edited form as:

Curr Opin Virol. 2016 October ; 20: 20-27. doi:10.1016/j.coviro.2016.07.011.

\title{
Merkel Cell Polyomavirus Infection and Merkel Cell Carcinoma
}

\author{
Wei Liu, Margo MacDonald, and Jianxin You ${ }^{\#}$ \\ Department of Microbiology, Perelman School of Medicine, University of Pennsylvania, \\ Philadelphia, PA 19104, USA
}

\section{Summary}

\begin{abstract}
Merkel cell polyomavirus is the only polyomavirus discovered to date that is associated with a human cancer. MCPyV infection is highly prevalent in the general population. Nearly all healthy adults asymptomatically shed MCPyV from their skin. However, in elderly and immunosuppressed individuals, the infection can lead to a lethal form of skin cancer, Merkel cell carcinoma. In the last few years, new findings have established links between MCPyV infection, host immune response, and Merkel cell carcinoma development. This review discusses these recent discoveries on how $\mathrm{MCPyV}$ interacts with host cells to achieve persistent infection and, in the immunocompromised population, contributes to MCC development.
\end{abstract}

\section{Introduction}

Merkel cell polyomavirus (MCPyV or MCV) has been linked to the development of a human cancer, Merkel cell carcinoma (MCC) [1**]. MCC, a neuroendocrine carcinoma of the skin, is one of the most aggressive skin cancers, with a disease-associated mortality of $46 \%$ [2]. MCC kills more patients than some other well-known cancers such as cutaneous Tcell lymphoma and chronic myelogenous leukemia [3,4].

Excessive exposure to sunlight and ultraviolet (UV) radiation, immune suppression, and advanced age are the major risk factors for MCC skin cancers [5,6]. MCC is therefore more frequently observed among people with fair skin, the elderly, and organ transplant or AIDS patients, with a strong predilection for the sun-exposed skin of the head and neck $[5,6]$. Clonal integration of MCPyV DNA into the host genome is a causal factor for the development of the majority of MCC tumors [7**].

$\mathrm{MCPyV}$ is also an abundant virus frequently detected on healthy human skin, suggesting that its infection is widespread in the general population [8-10]. Additional studies confirmed that exposure to the virus occurs in $80 \%$ or more of the general population [8*, 11,12]. Primary infection occurs during childhood. Once acquired, MCPyV becomes a lifelong component of the skin flora [13]. The strong association of MCC tumor development

\footnotetext{
\#Corresponding author: Jianxin You, jianyou@ mail.med.upenn.edu.

Publisher's Disclaimer: This is a PDF file of an unedited manuscript that has been accepted for publication. As a service to our customers we are providing this early version of the manuscript. The manuscript will undergo copyediting, typesetting, and review of the resulting proof before it is published in its final citable form. Please note that during the production process errors may be discovered which could affect the content, and all legal disclaimers that apply to the journal pertain.
} 
with immunosuppression suggests a viral causative link. The discovery of MCPyV in MCC tumors further supports a viral etiology for MCC [1**].

MCPyV is a small DNA virus with a circular, double-stranded DNA (dsDNA) genome of $\sim 5 \mathrm{~kb}$ [14]. The viral genome is divided into three major regions: the non-coding regulatory region (NCRR), which contains the viral origin of replication and transcriptional regulatory elements; the early coding region; and the late coding region [14,15]. The early region encodes large T (LT) antigen, small T (sT) antigen, the 57kT antigen, and a protein called alternative LT Open reading frame (ALTO) $\left[14,16^{* *}, 17^{* *}\right]$. The late region encodes the capsid proteins, VP1 and VP2 [18]. During the normal life cycle, the polyomavirus genome is maintained as a circular dsDNA episome (Fig. 1).

MCPyV genome and viral T antigens are detected in at least $80 \%$ of MCC cases, and expression of the $\mathrm{T}$ antigens is restricted to the tumor cells and not the surrounding healthy tissues [1,19-23]. Genetic analysis of MCPyV genome in these MCC tumors revealed that it is clonally integrated into the host cell genome $[1,24]$. The viral integration event appears to take place before the clonal expansion of tumor cell proliferation [1,25-27]. Persistent expression of MCPyV T antigens from the integrated viral genome is required for MCC tumor cells to survive [20*]. Together, these findings provide strong support for a causal role of MCPyV in the development of MCC skin cancer.

The incidence of MCC has tripled over the past twenty years as the aging population with prolonged sun exposure increases[28]. With the high prevalence of MCPyV infection and an increasing number of MCC diagnoses, there is a need to better understand the biology and oncogenic potentials of MCPyV. In this review, we summarize recent discoveries of the molecular mechanisms underlying MCPyV infection and associated oncogenesis.

\section{MCPyV oncogenes and cellular transformation}

A vital question in MCPyV research has been how MCPyV-encoded proteins contribute to viral activities and MCC development. Most of our knowledge of MCPyV oncogenic mechanisms was gained from studies of the viral oncogenes, LT and sT antigens, both of which have been implicated in MCPyV-induced tumorigenesis (See reviews [29**-31] for more detailed discussion on this subject). LT carries a J-domain (binds heat-shock proteins), retinoblastoma ( $\mathrm{RB}$ ) binding motif (inhibits RB family members), and the C-terminal originbinding and helicase/ATPase domains (required for viral DNA replication) [16**] (Fig. 2A). Much of the oncogenic function of LT antigen has been attributed to its high binding affinity for RB, which causes sequestration and inactivation of this tumor suppressor [32] (Fig. 2A). The RB binding function of MCPyV LT is required for sustained growth of MCPyV-positive MCC tumor both in vitro and in xenograft models [33]. MCPyV sT shares an N-terminal 78 amino acid region (harboring the $\mathrm{J}$-domain) with $\mathrm{LT}$ and carries a unique $\mathrm{C}$-terminal domain (Fig. 2A). Unlike other polyomaviruses, MCPyV sT is the major viral oncogene that contributes to virally-induced cellular transformation [22]. Expression of sT alone is sufficient to transform immortalized rodent fibroblasts [22] and also demonstrates transforming activity in vivo [34*]. sT accomplishes this function partly through maintaining the hyper-phosphorylated and inactivated state of the eukaryotic translation 
initiation factor 4E-binding protein 1 (4E-BP1), leading to dysregulation of cap-dependent translation that accelerates cell proliferation and malignant transformation [22]. sT also targets the cellular ubiquitin ligase $\mathrm{SCF}^{\mathrm{Fbw}} 7$ to inhibit proteasomal degradation of $\mathrm{MCPyV}$ LT and other cell-cycle regulators such as c-Myc and cyclin E, thus contributing to viral replication and host cell transformation [35*]. Unlike LT, nearly no mutations have been found in the sT-coding regions integrated into the genome of MCC tumors (Fig. 1), further confirming that the native MCPyV sT is needed to drive MCPyV-induced carcinogenesis.

MCPyV genomes discovered in many MCC tumors were frequently found to be integrated into the cellular genome, which resulted in tumor-specific truncation mutations that deleted the LT origin-binding and helicase domains needed for productive viral replication [16**]. Such integration events preserve expression of the native sT antigen and LT truncation mutants encoding the $\mathrm{N}$-terminal $\mathrm{J}$-domain and $\mathrm{RB}$ binding motif, but disrupt the $\mathrm{C}$-terminal regions of LT necessary for completion of the lytic viral replication cycle [1**,27]. Disruption of LT-mediated replication may protect MCPyV-infected cells from cell death induced by collisions of cellular DNA replication forks with the ones initiated from the viral origin [16**]. The clonal integration pattern of MCPyV suggests that viral infection and nonproductive integration of the MCPyV genomic DNA into the host cell genome occur prior to expansion of the MCC tumor cells $[1 * *, 7 * *, 36]$.

Truncation of the LT C-terminal origin-binding and helicase domains observed in integrated viral genomes found in MCC tumors also suggests that an unknown activity located in this region may antagonize tumor formation, and that there is a selective pressure to remove it during tumor development. Our group showed that expression of the LT C-terminal originbinding and helicase domains causes DNA damage and stimulates host DNA damage responses [37*]. This in turn leads to p53 activation and inhibition of cellular proliferation, which functions as a barrier to malignant progression [37*] (Fig. 2A). Suppression of cellular proliferation by a C-terminal region of MCPyV LT was also reported by Cheng et al., who mapped the MCPyV LT growth inhibitory properties to the C-terminal 100 residues of LT [38*]. We further demonstrated that phosphorylation of the MCPyV LT C-terminus by Ataxia telangiectasia mutated (ATM) kinase induces apoptosis and inhibits host proliferation, contributing to the C-terminal anti-tumorigenic properties of LT [39]. Together, these studies explain, in part, why deletion of the MCPyV LT C-terminus is necessary for the oncogenic progression of MCPyV-associated cancers (Fig. 2A).

\section{Target cells of MCPyV infection}

Despite the well-defined function of the viral oncogenes in cellular transformation described above, how MCPyV infection leads to MCC is not fully understood. Many aspects of the $\mathrm{MCPyV}$ infectious life cycle also remain unknown. This is largely because MCPyV replicates poorly in the majority of cell lines tested thus far [40-44] and the host cells naturally infected by MCPyV were previously unknown. Mechanistic studies to fully investigate MCPyV molecular biology and oncogenic mechanisms have thus been hampered by the lack of knowledge of the natural host cell tropism of MCPyV and the technical difficulties of propagating the virus in cell culture. In a recent study, our group identified human dermal fibroblasts as natural host cells that support productive MCPyV infection 
[45**]. We discovered that induction of matrix metalloproteinase (MMP) genes by the WNT/ $\beta$-catenin signaling pathway, along with other growth factors, stimulates MCPyV infection. This suggests that MCC risk factors, such as UV radiation and aging, which are known to stimulate WNT signaling and MMP expression, may promote viral infection and thereby drive MCC tumorigenesis (Fig. 2B) [45**].

\section{The cells of origin in MCC}

Historically, MCC tumors were thought to arise from Merkel cells, which are mechanoreceptor cells located in the basal layer of the epidermis that share the immunohistochemical marker Cytokeratin 20 (CK20) with MCC tumors (Table 1). However, new evidence suggests that MCC does not derive from mature Merkel cells [46]. For example, Merkel cells are post-mitotic and do not have proliferative activity, making them less likely to have tumorigenic potential [47,48]. In addition, Merkel cells are derived from the epidermal lineage [49,50], whereas MCC tumors mostly develop within the dermis and subcutis, without apparent connection to the epidermis [51]. These studies suggest that Merkel cells may not be the cells of origin for MCC. Because MCCs express Paired box gene 5 (PAX5) and terminal deoxynucleotidyl transferase (TdT), which are only expressed in pro/pre- and pre-B cells under physiological circumstances (Table 1), it has been speculated that MCC tumors may arise from pro-/pre-B cells, although this theory remains to be tested experimentally [ $52 * *$. In light of these recent findings, the true origin of MCC tumors remains unknown.

Identification of human dermal fibroblasts as the target cells of MCPyV infection presents new opportunities to understand how MCPyV-infected cells ultimately give rise to MCC tumors (Table 1). This finding is consistent with the fact that most MCC tumors develop in the human dermis [51]. It is possible that MCPyV infection of dermal fibroblasts induces their transformation and activates gene expression patterns of MCC tumors during the process of tumorigenesis (Fig. 3, Model 1). On the other hand, MCCs also express genes that are normally transcribed in benign Merkel cells [53*], suggesting that MCPyV infection may induce benign Merkel cells or progenitor cells to undergo malignant transformation. Along this line, $\mathrm{MCPyV}$ actively replicating in the dermal fibroblasts located at the boundary between epidermis and dermis may shed viral particles that inadvertently enter Merkel cells or their precursor cells present in the immediate vicinity within the basal layer of the epidermis (Fig. 3, Model 2) [45**]. MCPyV infection of bystander Merkel cells may cause MCC simply because Merkel cells represent a dead-end replication environment that favors viral integration and transformation. These scenarios remain to be tested in vivo using animal and human skin explant models.

\section{MCPyV infection, host immune responses, and MCC}

A complete understanding of how MCPyV drives MCC tumor development hinges on deciphering the interaction between MCPyV and the host immune system. The role of $\mathrm{MCPyV}$ in MCC development, along with the fact that immune-suppressed individuals are more likely to develop this cancer, indicate that the host immune response plays a key role in MCC tumorigenesis [54]. Additional evidence such as complete spontaneous tumor 
regression and tumor reactive $\mathrm{T}$ cells all support the role of the immune system in preventing and controlling MCC [55]. Furthermore, MCC patients with robust immune response generally have better prognoses, and high intratumoral CD8+ and CD4+ lymphocyte infiltration predicts better survival [56-58]. However, more than $90 \%$ of the MCC patients have normal immune function [59], and yet fail to clear the MCC tumors that express the non-self MCPyV oncoproteins. MCC tumors continue to develop despite the production of $\mathrm{T}$ cells recognizing $\mathrm{MCPyV}$ capsid proteins and oncoproteins that are immunogenic and persistently expressed in the tumors [60]. These facts argue that MCPyV-induced MCCs are capable of escaping immunological destruction. Indeed, the potential roles of MCPyV proteins in modulation of the immunological response of host cells have been demonstrated in recent studies.

One potential way in which MCPyV has been observed to avoid detection by the immune system is through downregulation of major histocompatibility complex class 1 (MHC-1). MHC-1 is necessary for presenting peptides from intracellular proteins to CD8+ T cells, making its downregulation an efficient mechanism for immune escape. In one study, $84 \%$ of MCC tumors showed MHC-1 downregulation, and MHC-1 expression was lower in MCPyV-positive tumors than in those that were MCPyV negative [61**]. Another way in which MCPyV evades the immune response is through downregulation of Toll-like Receptor 9 (TLR9), a critical sensor of the host innate immune response that recognizes viral and bacterial dsDNA [62]. This MCPyV function has been suggested to allow infected cells to escape host immune surveillance and may be critical for repressing host innate immune responses during $\mathrm{MCPyV}$-associated tumorigenesis [62]. MCPyV sT also down-regulates the expression of cellular genes associated with NF- $\mathrm{kB}$ pathways, which may subvert the host immune response to allow establishment of MCPyV persistent infection in the host cells $\left[63^{*}\right]$.

Additional work is needed to further elucidate the various mechanisms by which MCPyV escapes immune surveillance. MCPyV viral oncoproteins are not only specific and important for the growth of MCC cancer cells, but also foreign to the immune system. These key features of the viral oncogenes make them the idea targets of immunotherapy treatment for MCC. Once identified, the immune modulatory features of the viral proteins could also be subverted to induce antitumor immune response against MCPyV-positive tumor cells.

\section{Conclusions}

MCPyV is the only one of all 13 known human polyomaviruses that has been associated with cancer. MCPyV infection occurs at a young age and establishes a persistent infection. In time, either due to prolonged sunlight exposure, viral genome replication in dermal cells, or infection of bystander Merkel cells, a dead-end host, MCPyV genomes become integrated into the host genome. Proliferation of cells carrying integrated viral genomes selects for LT truncation mutations that promote efficient transformation. Induction of MMP by aging and prolonged UV exposure may favor a model of infection of bystander Merkel cells. Finally, immune downregulation by viral proteins allows $\mathrm{MCPyV}$ to establish a persistent infection; it may also play a role in supporting MCC tumors to persist and expand. Although MCC is a highly aggressive carcinoma, currently there is no effective therapeutic regime available for 
treating advanced stage MCC. Recent identification of human dermal fibroblasts as the major target of MCPyV infection in the human skin provides an exciting opportunity for studying the productive life cycle of this important oncogenic human polyomavirus.

Identification of the target cells of MCPyV natural infection will also facilitate establishment of new animal models to investigate MCPyV biology and oncogenic mechanisms in vivo. Persistent expression of $\mathrm{MCPyV}$ oncoproteins in $\mathrm{MCC}$ tumors and the dynamic interaction of viral proteins with the host immune system allow MCPyV to escape host immune surveillance. New insights into these immunomodulatory mechanisms are critical for the development of more effective virus-targeted immunotherapies for treating this lethal cancer.

\section{Acknowledgments}

The authors would like to thank the members of our laboratory for helpful discussion and Dr. Jason Diaz for editing the manuscript. This work was supported in part by the National Institutes of Health (NIH) Grants R01CA148768, R01CA142723, and R01CA187718.

\section{References}

Papers from the period under review that are of special interest $(*)$ or outstanding interest $(* *)$ have been highlighted and annotated.

1**. Feng H, Shuda M, Chang Y, Moore PS. Clonal integration of a polyomavirus in human Merkel cell carcinoma. Science. 2008; 319:1096-1100. This study discovers the presence of MCPyV in $80 \%$ of MCC tumors and suggests MCPyV is a contributing factor to MCC tumorigenesis. [PubMed: 18202256]

2. Lemos BD, Storer BE, Iyer JG, Phillips JL, Bichakjian CK, Fang LC, Johnson TM, Liegeois-Kwon NJ, Otley CC, Paulson KG, et al. Pathologic nodal evaluation improves prognostic accuracy in Merkel cell carcinoma: analysis of 5823 cases as the basis of the first consensus staging system. $\mathbf{J}$ Am Acad Dermatol. 2010; 63:751-761. [PubMed: 20646783]

3. Lemos B, Nghiem P. Merkel cell carcinoma: more deaths but still no pathway to blame. J Invest Dermatol. 2007; 127:2100-2103. [PubMed: 17700621]

4. Weinstock MA, Gardstein B. Twenty-year trends in the reported incidence of mycosis fungoides and associated mortality. Am J Public Health. 1999; 89:1240-1244. [PubMed: 10432915]

5. Engels EA, Frisch M, Goedert JJ, Biggar RJ, Miller RW. Merkel cell carcinoma and HIV infection. Lancet. 2002; 359:497-498. [PubMed: 11853800]

6. Locke FL, Rollison DE, Sondak VK. Merkel cell carcinoma and immunosuppression: what we still need to know. J Natl Cancer Inst. 2015; 107

7**. Chang Y, Moore PS. Merkel cell carcinoma: a virus-induced human cancer. Annu Rev Pathol. 2012; 7:123-144. This review discusses the genomic organization of MCPyV, the molecular biology and pathology of both MCPyV and MCC, and the epidemiology of MCPyV and MCC. [PubMed: 21942528]

8*. Tolstov YL, Pastrana DV, Feng H, Becker JC, Jenkins FJ, Moschos S, Chang Y, Buck CB, Moore PS. Human Merkel cell polyomavirus infection II. MCV is a common human infection that can be detected by conformational capsid epitope immunoassays. Int J Cancer. 2009; 125:1250-1256. This study shows that, although it was previously unrecognized, MCPyV infection is widespread in the human population, and that MCC patients have elevated MCPyV IgG response compared to controls. [PubMed: 19499548]

9**. Schowalter RM, Pastrana DV, Pumphrey KA, Moyer AL, Buck CB. Merkel cell polyomavirus and two previously unknown polyomaviruses are chronically shed from human skin. Cell Host Microbe. 2010; 7:509-515. This study isolated complete, wild-type cloned genomes of MCPyV, and also discovered the existence of two previously unknown polyomaviruses, human polyomavirus-6 and human polyomavirus-7. [PubMed: 20542254] 
10. Foulongne V, Sauvage V, Hebert C, Dereure O, Cheval J, Gouilh MA, Pariente K, Segondy M, Burguière A, Manuguerra J-C, et al. Human Skin Microbiota: High Diversity of DNA Viruses Identified on the Human Skin by High Throughput Sequencing. PLoS One. 2012; 7:e38499. [PubMed: 22723863]

11. Kean JM, Rao S, Wang M, Garcea RL. Seroepidemiology of human polyomaviruses. PLoS Pathog. 2009; 5:e1000363. [PubMed: 19325891]

12. Pastrana DV, Tolstov YL, Becker JC, Moore PS, Chang Y, Buck CB. Quantitation of human seroresponsiveness to Merkel cell polyomavirus. PLoS Pathog. 2009; 5:e1000578. [PubMed: 19750217]

13. Chen T, Hedman L, Mattila PS, Jartti T, Ruuskanen O, Soderlund-Venermo M, Hedman K. Serological evidence of Merkel cell polyomavirus primary infections in childhood. J Clin Virol. 2011; 50:125-129. [PubMed: 21094082]

14. Gjoerup, O.; Chang, Y. Chapter 1 - Update on Human Polyomaviruses and Cancer. In: George, FVW.; George, K., editors. Advances in Cancer Research. Vol. 106. Academic Press; 2010. p. $1-51$.

15. Johne R, Buck CB, Allander T, Atwood WJ, Garcea RL, Imperiale MJ, Major EO, Ramqvist T, Norkin LC. Taxonomical developments in the family Polyomaviridae. Arch Virol. 2011; 156:1627-1634. [PubMed: 21562881]

16**. Shuda M, Feng H, Kwun HJ, Rosen ST, Gjoerup O, Moore PS, Chang Y. T antigen mutations are a human tumor-specific signature for Merkel cell polyomavirus. Proc Natl Acad Sci U S A. 2008; 105:16272-16277. This article shows that LT antigen is truncated in MCC tumor cells, eliminating viral DNA replication capacity by removing the origin binding and helicase domains, preventing autoactivation of integrated virus replication that would threaten cell survival. [PubMed: 18812503]

17**. Carter JJ, Daugherty MD, Qi X, Bheda-Malge A, Wipf GC, Robinson K, Roman A, Malik HS, Galloway DA. Identification of an overprinting gene in Merkel cell polyomavirus provides evolutionary insight into the birth of viral genes. Proc Natl Acad Sci U S A. 2013; 110:1274412749. This article identifies an overprinting gene, alternate LT ORF (ALTO), in MCPyV and other polyomaviruses. [PubMed: 23847207]

18. Schowalter RM, Buck CB. The Merkel cell polyomavirus minor capsid protein. PLoS Pathog. 2013; 9:e1003558. [PubMed: 23990782]

19. Busam KJ, Jungbluth AA, Rekthman N, Coit D, Pulitzer M, Bini J, Arora R, Hanson NC, Tassello JA, Frosina D, et al. Merkel cell polyomavirus expression in merkel cell carcinomas and its absence in combined tumors and pulmonary neuroendocrine carcinomas. Am J Surg Pathol. 2009; 33:1378-1385. [PubMed: 19609205]

20*. Houben R, Shuda M, Weinkam R, Schrama D, Feng H, Chang Y, Moore PS, Becker JC. Merkel cell polyomavirus-infected Merkel cell carcinoma cells require expression of viral T antigens. J Virol. 2010; 84:7064-7072. This article shows that viral T antigen expression is necessary for the maintenance of MCPyV-positive MCC. This study provides direct evidence that MCPyV is the infectious cause of MCPyV-positive MCC. [PubMed: 20444890]

21. Shuda M, Arora R, Kwun HJ, Feng H, Sarid R, Fernandez-Figueras MT, Tolstov Y, Gjoerup O, Mansukhani MM, Swerdlow SH, et al. Human Merkel cell polyomavirus infection I. MCV T antigen expression in Merkel cell carcinoma, lymphoid tissues and lymphoid tumors. Int J Cancer. 2009; 125:1243-1249. [PubMed: 19499546]

22. Shuda M, Kwun HJ, Feng H, Chang Y, Moore PS. Human Merkel cell polyomavirus small T antigen is an oncoprotein targeting the 4E-BP1 translation regulator. J Clin Invest. 2011; 121:3623-3634. [PubMed: 21841310]

23. Rodig SJ, Cheng J, Wardzala J, DoRosario A, Scanlon JJ, Laga AC, Martinez-Fernandez A, Barletta JA, Bellizzi AM, Sadasivam S, et al. Improved detection suggests all Merkel cell carcinomas harbor Merkel polyomavirus. J Clin Invest. 2012; 122:4645-4653. [PubMed: 23114601]

24. Amber K, McLeod MP, Nouri K. The Merkel cell polyomavirus and its involvement in Merkel cell carcinoma. Dermatol Surg. 2013; 39:232-238. [PubMed: 23387356]

25. Laude HC, Jonchere B, Maubec E, Carlotti A, Marinho E, Couturaud B, Peter M, Sastre-Garau X, Avril MF, Dupin N, et al. Distinct merkel cell polyomavirus molecular features in tumour and non 
tumour specimens from patients with merkel cell carcinoma. PLoS Pathog. 2010; 6:e1001076. [PubMed: 20865165]

26. de Biase D, Ragazzi M, Asioli S, Eusebi V. Extracutaneous Merkel cell carcinomas harbor polyomavirus DNA. Hum Pathol. 2012; 43:980-985. [PubMed: 22204708]

27. Sastre-Garau X, Peter M, Avril MF, Laude H, Couturier J, Rozenberg F, Almeida A, Boitier F, Carlotti A, Couturaud B, et al. Merkel cell carcinoma of the skin: pathological and molecular evidence for a causative role of MCV in oncogenesis. J Pathol. 2009; 218:48-56. [PubMed: 19291712]

28. Hodgson NC. Merkel cell carcinoma: Changing incidence trends. Journal of Surgical Oncology. 2005; 89:1-4. [PubMed: 15611998]

$29 * *$. Grundhoff A, Fischer N. Merkel cell polyomavirus, a highly prevalent virus with tumorigenic potential. Curr Opin Virol. 2015; 14:129-137. This review discusses MCPyV biology and the unique features that distinguish MCPyV from other polyomaviruses. [PubMed: 26447560]

30. Wendzicki JA, Moore PS, Chang Y. Large T and small T antigens of Merkel cell polyomavirus. Curr Opin Virol. 2015; 11:38-43. [PubMed: 25681708]

31. Spurgeon ME, Lambert PF. Merkel cell polyomavirus: a newly discovered human virus with oncogenic potential. Virology. 2013; 435:118-130. [PubMed: 23217622]

32. Borchert S, Czech-Sioli M, Neumann F, Schmidt C, Wimmer P, Dobner T, Grundhoff A, Fischer N. High-affinity Rb binding, p53 inhibition, subcellular localization, and transformation by wildtype or tumor-derived shortened Merkel cell polyomavirus large T antigens. J Virol. 2014; 88:3144-3160. [PubMed: 24371076]

33. Houben R, Adam C, Baeurle A, Hesbacher S, Grimm J, Angermeyer S, Henzel K, Hauser S, Elling $\mathrm{R}$, Brocker EB, et al. An intact retinoblastoma protein-binding site in Merkel cell polyomavirus large $\mathrm{T}$ antigen is required for promoting growth of Merkel cell carcinoma cells. Int $\mathrm{J}$ Cancer. 2012; 130:847-856. [PubMed: 21413015]

34*. Verhaegen ME, Mangelberger D, Harms PW, Vozheiko TD, Weick JW, Wilbert DM, Saunders TL, Ermilov AN, Bichakjian CK, Johnson TM, et al. Merkel Cell Polyomavirus Small T Antigen Is Oncogenic in Transgenic Mice. J Invest Dermatol. 2014 This article demonstrates transforming activity of MCPyV sT antigen in vivo using a panel of transgenic mouse models. The result implicates sT antigen as an oncogenic driver in MCC.

35*. Kwun HJ, Shuda M, Feng H, Camacho CJ, Moore PS, Chang Y. Merkel cell polyomavirus small $\mathrm{T}$ antigen controls viral replication and oncoprotein expression by targeting the cellular ubiquitin ligase SCFFbw7. Cell Host Microbe. 2013; 14:125-135. This article shows that MCPyV sT contributes to viral DNA replication mediated by the LT helicase through inhibiting the cellular $\mathrm{SCF}^{\mathrm{Fbw} 7} \mathrm{E} 3$ ligase that targets LT for proteasomal degradation. [PubMed: 23954152]

36. Houben R, Schrama D, Becker JC. Molecular pathogenesis of Merkel cell carcinoma. Exp Dermatol. 2009; 18:193-198. [PubMed: 19400830]

37*. Li J, Wang X, Diaz J, Tsang SH, Buck CB, You J. Merkel cell polyomavirus large T antigen disrupts host genomic integrity and inhibits cellular proliferation. J Virol. 2013; 87:9173-9188. This article shows that the helicase-containing region of the MCPyV LT activates host DNA damage responses and enhanced p53 phosphorylation, thus contributing to the full-length LT antitumorigenic activity. [PubMed: 23760247]

38*. Cheng J, Rozenblatt-Rosen O, Paulson KG, Nghiem P, DeCaprio JA. Merkel cell polyomavirus large $\mathrm{T}$ antigen has growth-promoting and inhibitory activities. J Virol. 2013; 87:6118-6126. This article shows that MCPyV LT has both growth-promoting and inhibitory properties, depending on whether or not its $\mathrm{C}$ terminus has been truncated. This study also mapped the MCPyV large T growth-inhibitory function to the $\mathrm{C}$-terminal 100 residues region. [PubMed: 23514892]

39. Li J, Diaz J, Wang X, Tsang SH, You J. Phosphorylation of Merkel Cell Polyomavirus Large Tumor Antigen at Serine 816 by ATM Kinase Induces Apoptosis in Host Cells. J Biol Chem. 2015; 290:1874-1884. [PubMed: 25480786]

40. Feng H, Kwun HJ, Liu X, Gjoerup O, Stolz DB, Chang Y, Moore PS. Cellular and viral factors regulating Merkel cell polyomavirus replication. PLoS One. 2011; 6:e22468. [PubMed: 21799863] 
41. Schowalter RM, Pastrana DV, Buck CB. Glycosaminoglycans and sialylated glycans sequentially facilitate Merkel cell polyomavirus infectious entry. PLoS Pathog. 2011; 7:e1002161. [PubMed: 21829355]

42. Neumann F, Borchert S, Schmidt C, Reimer R, Hohenberg H, Fischer N, Grundhoff A. Replication, Gene Expression and Particle Production by a Consensus Merkel Cell Polyomavirus (MCPyV) Genome. PLoS One. 2011; 6:e29112. [PubMed: 22216177]

43. Schowalter RM, Reinhold WC, Buck CB. Entry Tropism of BK and Merkel Cell Polyomaviruses in Cell Culture. PLoS ONE. 2012; 7:e42181. [PubMed: 22860078]

44. Tsang SH, Wang X, Li J, Buck CB, You J. Host DNA Damage Response Factors Localize to Merkel Cell Polyomavirus DNA Replication Sites to Support Efficient Viral DNA Replication. J Virol. 2014; 88:3285-3297. [PubMed: 24390338]

45**. Liu W, Yang R, Payne AS, Schowalter RM, Spurgeon ME, Lambert PF, Xu X, Buck CB, You J. Identifying the Target Cells and Mechanisms of Merkel Cell Polyomavirus Infection. Cell Host Microbe. 2016 This article identifies human dermal fibroblasts as the natural host cells supporting productive $\mathrm{MCPyV}$ infection. It shows that induction of matrix metalloproteinase genes by the WNT/ $\beta$-catenin signaling pathway stimulates viral infection, identifying MEK antagonist trametinib as an effective inhibitor.

46. Tilling T, Moll I. Which are the cells of origin in merkel cell carcinoma? J Skin Cancer. 2012; 2012:680410. [PubMed: 23304516]

47. Vaigot P, Pisani A, Darmon YM, Ortonne JP. The majority of epidermal Merkel cells are nonproliferative: a quantitative immunofluorescence analysis. Acta Derm Venereol. 1987; 67:517520. [PubMed: 2451378]

48. Moll I, Zieger W, Schmelz M. Proliferative Merkel cells were not detected in human skin. Arch Dermatol Res. 1996; 288:184-187. [PubMed: 8967790]

49. Morrison KM, Miesegaes GR, Lumpkin EA, Maricich SM. Mammalian Merkel cells are descended from the epidermal lineage. Dev Biol. 2009; 336:76-83. [PubMed: 19782676]

50. Van Keymeulen A, Mascre G, Youseff KK, Harel I, Michaux C, De Geest N, Szpalski C, Achouri Y, Bloch W, Hassan BA, et al. Epidermal progenitors give rise to Merkel cells during embryonic development and adult homeostasis. J Cell Biol. 2009; 187:91-100. [PubMed: 19786578]

51. Calder KB, Smoller BR. New insights into merkel cell carcinoma. Adv Anat Pathol. 2010; 17:155161. [PubMed: 20418670]

52**. Zur Hausen A, Rennspiess D, Winnepenninckx V, Speel EJ, Kurz AK. Early B-cell differentiation in Merkel cell carcinomas: clues to cellular ancestry. Cancer Res. 2013 This article shows that all MCC tumors tested expressed PAX5, and many expressed TdT. This coexpression is restricted to pro/pre- and pre-B cells under physiologic circumstances, indicating that MCCs possibly derive from these cells rather than Merkel cells.

53*. Harms PW, Patel RM, Verhaegen ME, Giordano TJ, Nash KT, Johnson CN, Daignault S, Thomas DG, Gudjonsson JE, Elder JT, et al. Distinct gene expression profiles of viral- and nonviralassociated merkel cell carcinoma revealed by transcriptome analysis. J Invest Dermatol. 2013; 133:936-945. This article shows the result of a DNA microarray analysis comparing the gene expression profiles of MCPyV-negative and MCPyV-positive MCC tumors, suggesting that loss of $R B 1$ expression may be a critical contributing factor for MCPyV-negative tumorigenesis. [PubMed: 23223137]

54. Ma JE, Brewer JD. Merkel cell carcinoma in immunosuppressed patients. Cancers (Basel). 2014; 6:1328-1350. [PubMed: 24978436]

55. Triozzi PL, Fernandez AP. The role of the immune response in merkel cell carcinoma. Cancers (Basel). 2013; 5:234-254. [PubMed: 24216706]

56. Sihto H, Bohling T, Kavola H, Koljonen V, Salmi M, Jalkanen S, Joensuu H. Tumor infiltrating immune cells and outcome of Merkel cell carcinoma: a population-based study. Clin Cancer Res. 2012; 18:2872-2881. [PubMed: 22467679]

57. Paulson KG, Iyer JG, Tegeder AR, Thibodeau R, Schelter J, Koba S, Schrama D, Simonson WT, Lemos BD, Byrd DR, et al. Transcriptome-wide studies of merkel cell carcinoma and validation of intratumoral CD8+ lymphocyte invasion as an independent predictor of survival. J Clin Oncol. 2011; 29:1539-1546. [PubMed: 21422430] 
58. Sihto H, Joensuu H. Tumor-infiltrating lymphocytes and outcome in Merkel cell carcinoma, a virus-associated cancer. Oncoimmunology. 2012; 1:1420-1421. [PubMed: 23243614]

59. Heath M, Jaimes N, Lemos B, Mostaghimi A, Wang LC, Peñas PF, Nghiem P. Clinical characteristics of Merkel cell carcinoma at diagnosis in 195 patients: the AEIOU features. Journal of the American Academy of Dermatology. 2008; 58:375-381. [PubMed: 18280333]

60. Iyer JG, Afanasiev OK, McClurkan C, Paulson K, Nagase K, Jing L, Marshak JO, Dong L, Carter J, Lai I, et al. Merkel cell polyomavirus-specific CD8(+) and CD4(+) T-cell responses identified in Merkel cell carcinomas and blood. Clin Cancer Res. 2011; 17:6671-6680. [PubMed: 21908576]

61**. Paulson KG, Tegeder A, Willmes C, Iyer JG, Afanasiev OK, Schrama D, Koba S, Thibodeau R, Nagase K, Simonson WT, et al. Downregulation of MHC-I expression is prevalent but reversible in Merkel cell carcinoma. Cancer Immunol Res. 2014; 2:1071-1079. This article demonstrates MHC-1 downregulation in MCC tumors, especially those infected with MCPyV. The downregulation was multifactorial, depending on more than just HLA gene expression, but was reversible with interferon treatment. [PubMed: 25116754]

62. Shahzad N, Shuda M, Gheit T, Kwun HJ, Cornet I, Saidj D, Zannetti C, Hasan U, Chang Y, Moore PS, et al. The T antigen locus of Merkel cell polyomavirus downregulates human Toll-like receptor 9 expression. J Virol. 2013; 87:13009-13019. [PubMed: 24067965]

63*. Griffiths DA, Abdul-Sada H, Knight LM, Jackson BR, Richards K, Prescott EL, Peach AH, Blair GE, Macdonald A, Whitehouse A. Merkel cell polyomavirus small T antigen targets the NEMO adaptor protein to disrupt inflammatory signaling. J Virol. 2013; 87:13853-13867. This article shows that MCPyV sT inhibits NF- $\mathrm{BB}$-mediated cellular gene transcription, allowing MCPyV to subvert the innate immune response. [PubMed: 24109239]

64. Houben R, Angermeyer S, Haferkamp S, Aue A, Goebeler M, Schrama D, Hesbacher S. Characterization of functional domains in the Merkel cell polyoma virus Large $\mathrm{T}$ antigen. Int $\mathrm{J}$ Cancer. 2015; 136:E290-300. [PubMed: 25208506]

65. Martel-Jantin C, Filippone C, Cassar O, Peter M, Tomasic G, Vielh P, Briere J, Petrella T, AubriotLorton $\mathrm{MH}$, Mortier L, et al. Genetic variability and integration of Merkel cell polyomavirus in Merkel cell carcinoma. Virology. 2012; 426:134-142. [PubMed: 22342276] 


\section{Highlights}

- $\quad \mathrm{MCPyV}$ infection is highly prevalent in the general population, but in elderly and immunosuppressed individuals, causes a lethal form of skin cancer, Merkel cell carcinoma

- $\quad$ MCPyV LT and sT antigens are the key oncogenes that drive MCPyVinduced tumorigenesis

- Human dermal fibroblasts have been recently discovered to be the natural host cells that support productive MCPyV infection in human skin

- $\quad$ Induction of matrix metalloproteinase genes by growth factors and WNT signaling stimulates MCPyV infection

- $\quad$ Elucidation of the mechanisms by which MCPyV escapes immune surveillance are critical for the development of more effective virustargeted immunotherapies for treating the highly lethal Merkel cell carcinoma 


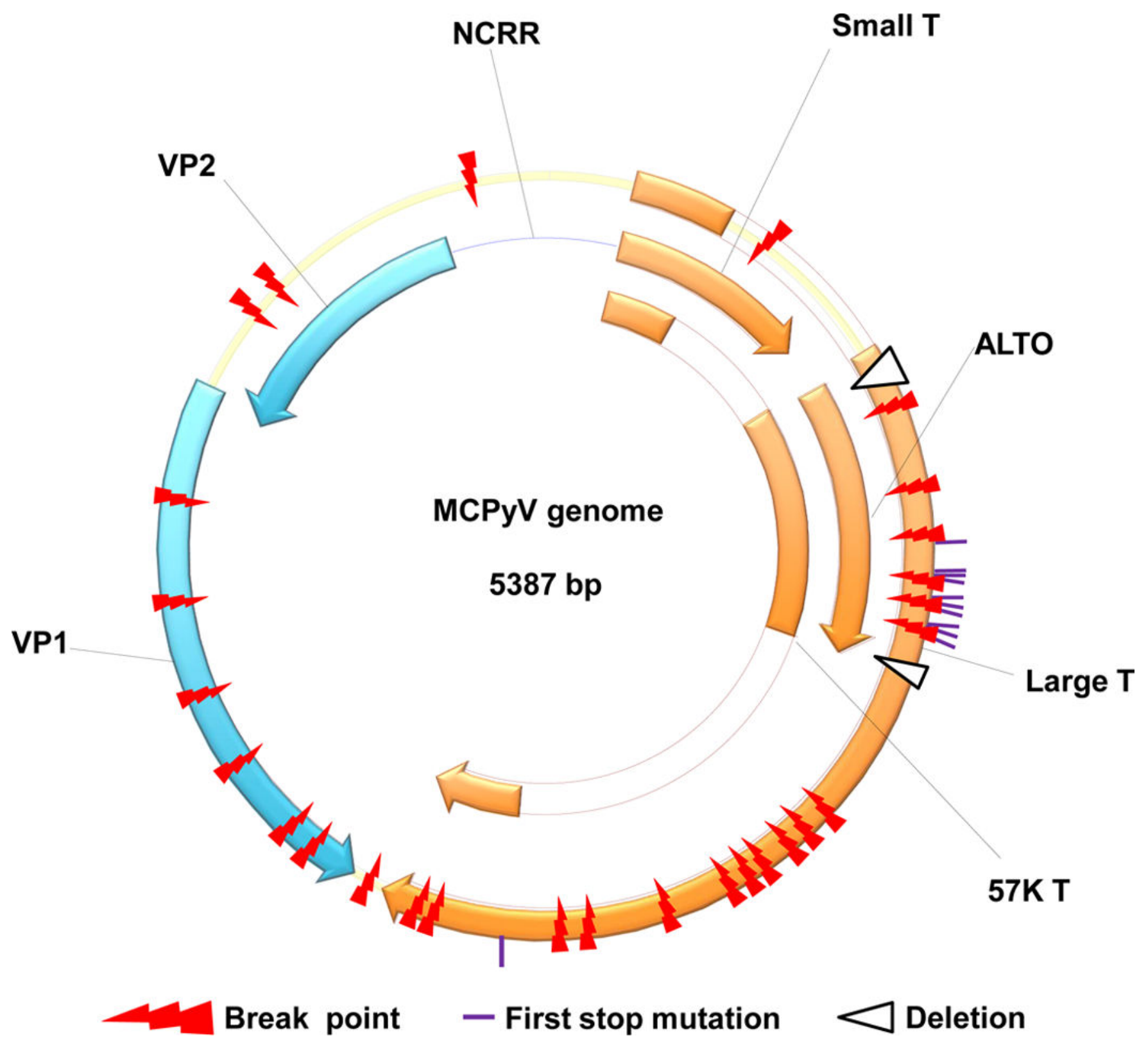

Figure 1. An intact MCPyV sT antigen-coding sequence is found in nearly all of the viral genomes integrated into MCC tumors

Analysis of 30 sequences of MCPyV-positive MCC obtained from published studies [1**, $16 * *, 25,42,64,65]$ show that all of them encode a wild type sT gene. The break points represent the break sites of the integrated MCPyV genomes. The first stop mutations are the first stop codons found in the $\mathrm{T}$ antigen sequences of the integrated MCPyV genomes. 


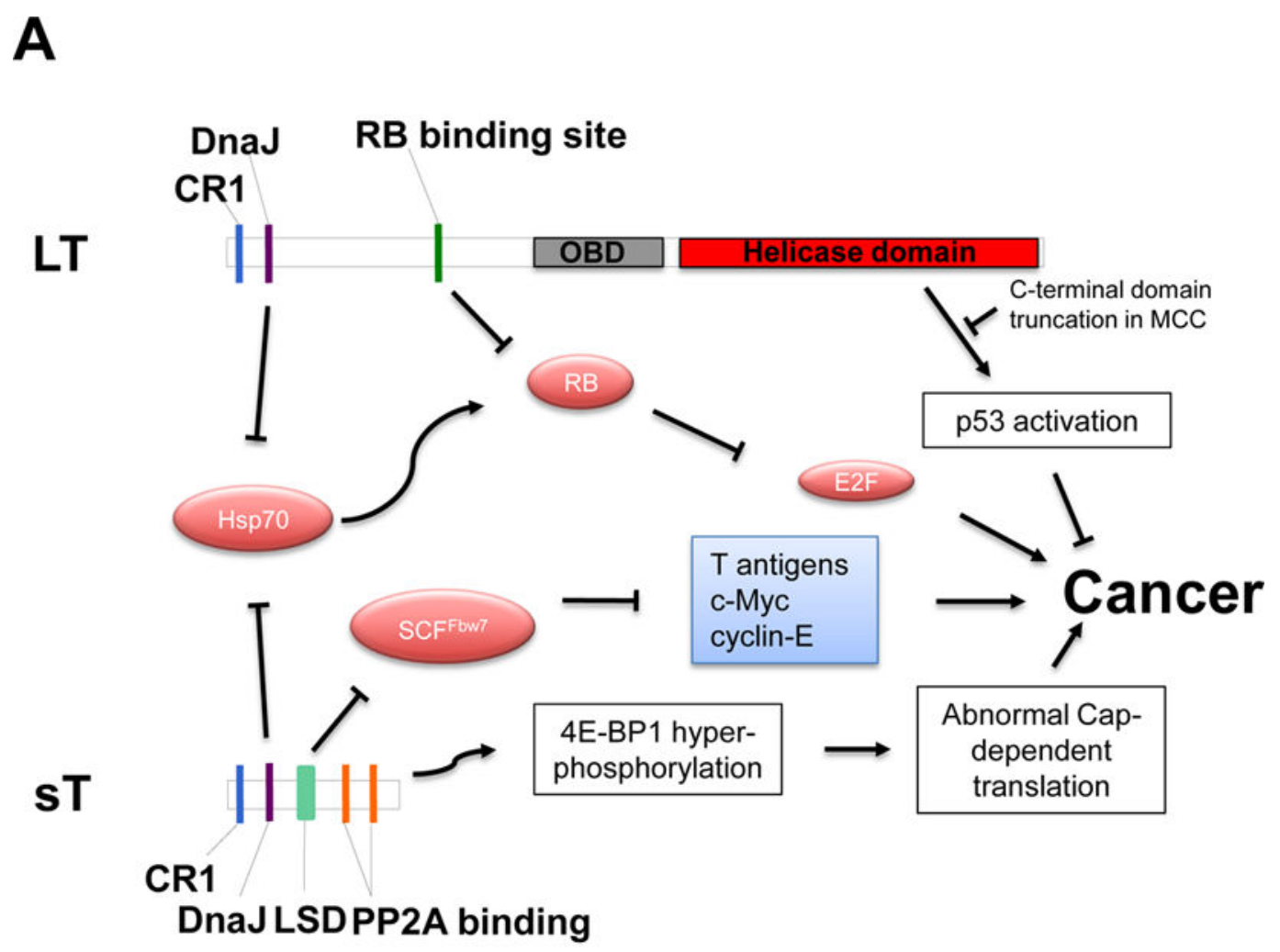

B

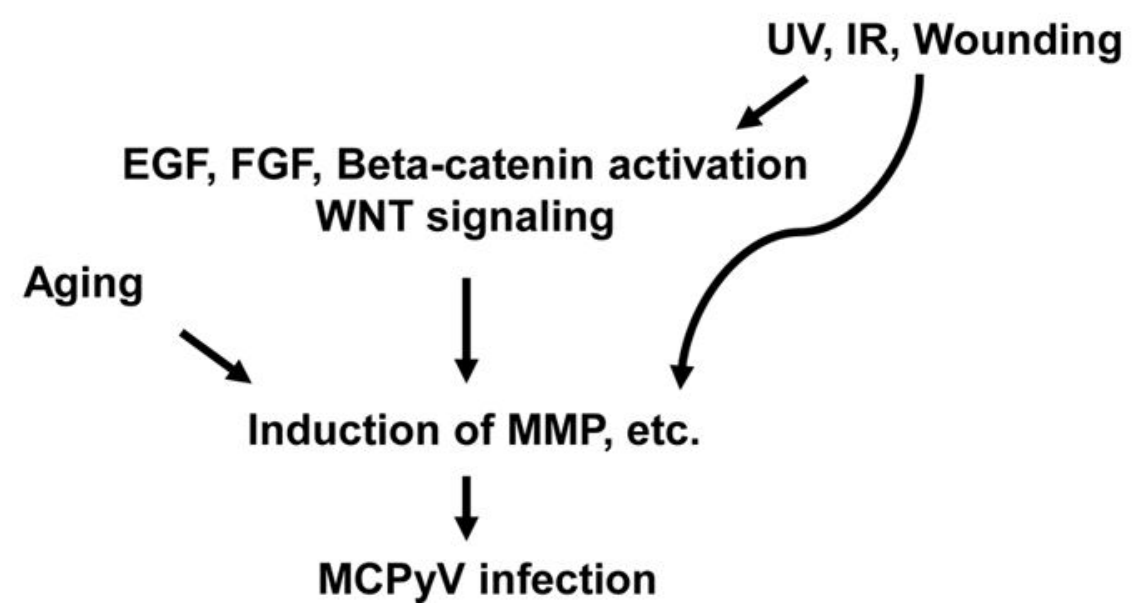

Figure 2. Molecular and cellular events contributing to MCPyV infection and MCC tumorigenesis

A. MCPyV oncoproteins drive cellular transformation through interaction with host proteins. Shown are the domain structures of MCPyV LT and sT as well as the cellular targets that they interact with to drive cancer development. CR1: conserved region 1; OBD: Origin Binding Domain; LSD: LT-stabilization domain. B. Molecular signaling contributing to MCPyV infection. Induction of MMP genes by the WNT/ $\beta$-catenin signaling pathway and other growth factors, such as EGF and FGF, stimulates MCPyV 
infection. MMPs may contribute to MCPyV infection by disrupting the extracellular matrix of the host cells. In the physiological skin environment, skin damage induced by UV/ ionizing radiation (IR) and wounding processes can activate both WNT signaling and MMP expression. Aging skin also shows dramatically increased MMP expression. Therefore, these major MCC risk factors may promote viral infection to drive MCC tumorigenesis. 


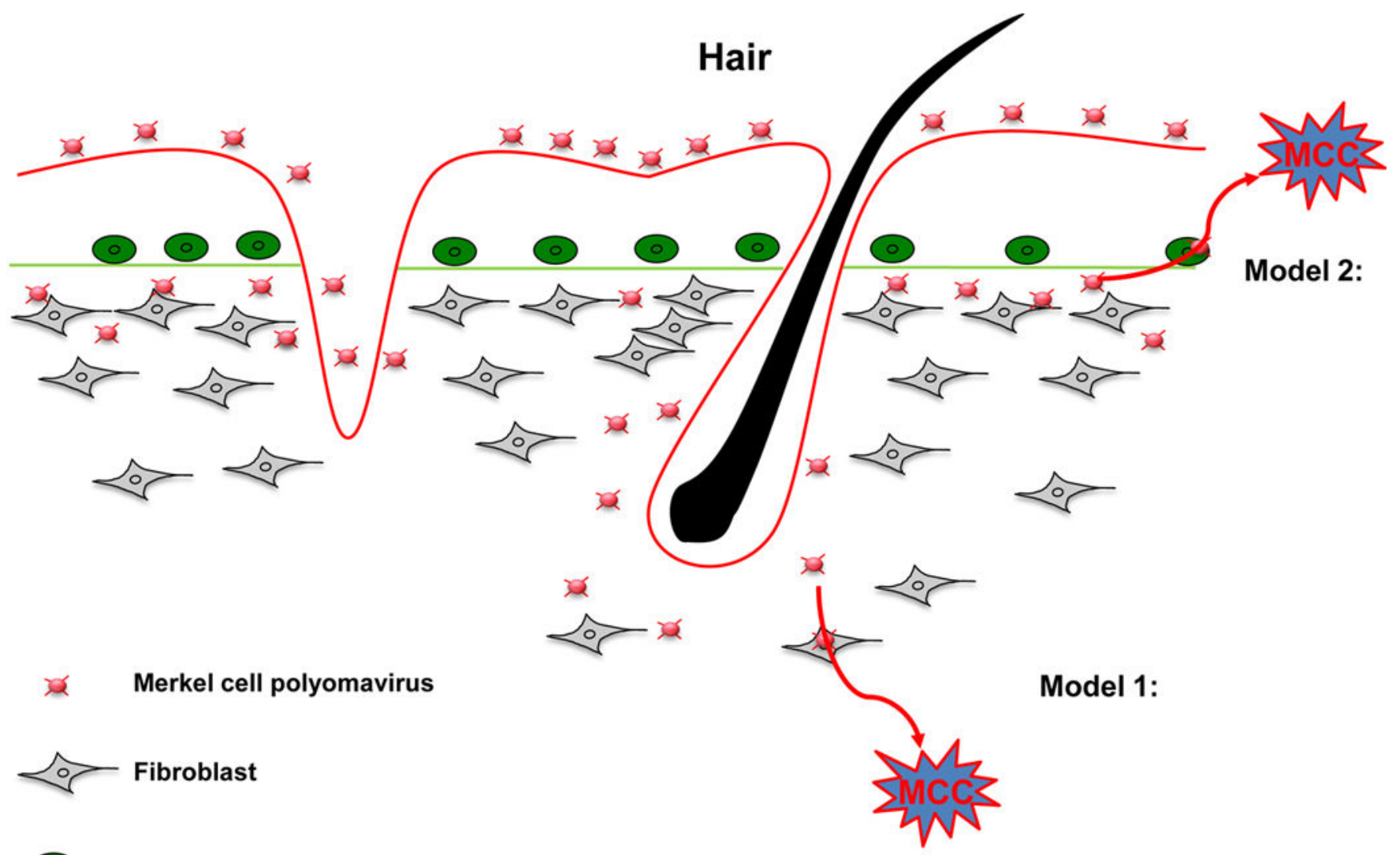

Merkel cell

Figure 3. The working models for MCPyV infection and MCC development

Human dermal fibroblasts are the major target cells of MCPyV infection in the human skin. Shown are two working models for understanding how MCPyV-infected cells may give rise to MCC tumors. MCPyV infection of dermal fibroblasts could induce their transformation (Model 1). Alternatively, benign Merkel cells or progenitor cells located in the immediate vicinity of the infected dermal fibroblasts could be infected as accidental bystanders. MCPyV infection of Merkel cells may lead to MCC because these cells represent a dead-end replication environment that promotes viral integration and transformation (Model 2). 


\section{Table 1}

Potential cells of origin for MCC and their shared markers/features with MCC

\begin{tabular}{|l|l|l|}
\hline & Markers/features & References \\
\hline Merkel cell carcinoma & CK20+, NSE+, PAX5+, NSP+, TdT+, TTF-1-, LCA-, S100- & {$\left[{ }^{1-4}\right]$} \\
\hline Merkel cells & CK20+, Electron microscope morphology & {$[5,6]$} \\
\hline Pro/pre-B and pre-B cells & PAX5+, TdT+ & {$[7,]^{5}$} \\
\hline Dermal fibroblasts & Major target of MCPyV infection, support productive viral transcription and replication & {$\left[{ }^{9}\right]$} \\
\hline
\end{tabular}

CK20: Cytokeratin 20; NSE: neuron-specific enolase; NFP: neurofilament protein; PAX5: Paired box gene 5; TdT: terminal deoxynucleotidyl transferase; LCA: leukocyte common antigen; TTF-1: thyroid transcription factor 1.

\section{References}

1 Zur Hausen A, Rennspiess D, Winnepenninckx V, Speel EJ, Kurz AK: Early B-cell differentiation in Merkel cell carcinomas: clues to cellular ancestry. Cancer Res 2013, 73:4982-4987.

2 Ratner D, Nelson BR, Brown MD, Johnson TM: Merkel cell carcinoma. J Am Acad Dermatol 1993, 29:143-156.

3 Leff EL, Brooks JS, Trojanowski JQ: Expression of neurofilament and neuron-specific enolase in small cell tumors of skin using immunohistochemistry. Cancer 1985, 56:625-631.

${ }^{4}$ Chan JK, Suster S, Wenig BM, Tsang WY, Chan JB, Lau AL: Cytokeratin 20 immunoreactivity distinguishes Merkel cell (primary cutaneous neuroendocrine) carcinomas and salivary gland small cell carcinomas from small cell carcinomas of various sites. Am J Surg Pathol 1997, 21:226234.

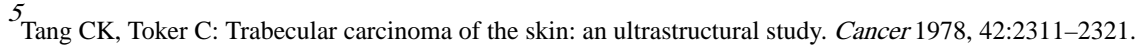

${ }^{6}$ Moll I, Kuhn C, Moll R: Cytokeratin 20 is a general marker of cutaneous Merkel cells while certain neuronal proteins are absent. J Invest Dermatol 1995, 104:910-915.

7 Gore SD, Kastan MB, Civin CI: Normal human bone marrow precursors that express terminal deoxynucleotidyl transferase include T-cell precursors and possible lymphoid stem cells. Blood 1991, 77:1681-1690.

8 Adams B, Dorfler P, Aguzzi A, Kozmik Z, Urbanek P, Maurer-Fogy I, Busslinger M: Pax-5 encodes the transcription factor BSAP and is expressed in B lymphocytes, the developing CNS, and adult testis. Genes Dev 1992, 6:1589-1607.

9 Liu W, Yang R, Payne AS, Schowalter RM, Spurgeon ME, Lambert PF, Xu X, Buck CB, You J: Identifying the Target Cells and Mechanisms of Merkel Cell Polyomavirus Infection. Cell Host Microbe 2016, 19:775-787. 